\title{
PENANAMAN NILAI-NILAI PENDIDIKAN KARAKTER DISIPLIN PADA SISWA SEKOLAH DASAR
}

\author{
(Inserting of Discipline Character Education Values in Basic School Students)
}

\author{
oleh: Fadillah Annisa ${ }^{*}$ \\ E-mail : Fadillahannisa95@yahoo.co.id
}

*) Program Studi Pendidikan Dasar Program Pascasarjana Universitas Negeri Padang

\begin{abstract}
This study aims to describe the implementation of disciplinary character education in elementary schools and is expected to be able to find policies that support the success of character education. This type of research uses a qualitative approach. The study was conducted at SDN 29 Lubuk Alung, with the subject of principals, teachers, and students. Data is collected through observation, interviews, and documentation. The data validity checking technique used is the triangulation technique. The results showed that in carrying out disciplinary character education at SDN 29 Lubuk Alung through six policies, namely (1) making character education programs, (2) establishing school rules and class rules, (3) doing Dhuha prayer and Dhuhur prayer in congregation, ( 4) making affective posts in each class, (5) monitoring the discipline behavior of students at home through a daily activity logbook, (6) involving parents (7) involving the school committee.

Keywords: Discipline Character Education, Elementary School
\end{abstract}

\section{PENDAHULUAN}

Pendidikan tidak terlepas dari kehidupan sehari-hari karena apa yang dipelajari di dalam dunia pendidikan sesuai dengan kehidupan nyata yang dialami oleh peserta didik. Setiap peserta didik menempuh pendidikan sebagai bekal kehidupan, baik bagi dirinya sendiri, masyarakat, bangsa maupun negara. Seiring zaman yang semakin modern, pendidikan hendaknya dipersiapkan untuk memberikan bekal ilmu pengetahuan tentang moral, kreatif dan cerdas terhadap peserta didik, guna mempersiapkan diri menghadapi tuntutan zaman. Hal tersebut tidak lepas dari kualitas pendidikan itu sendiri.

Tujuan pendidikan sebagaimana yang tersirat di dalam UUD 1945 yaitu mencerdaskan kehidupan bangsa. Bangsa yang cerdas tentunya bukan hanya bangsa yang dapat bekerja. Tetapi bangsa yang juga dapat mencapai pendidikan berkualitas, yaitu pendidikan yang mampu meningkatkan mutu individu maupun masyarakat secara keseluruhan.
Undang-undang Sistem Pendidikan Nasional No. 20 Tahun 2003 menjelaskan bahwa pendidikan nasional berfungsi mengembangkan kemampuan dan membentuk watak serta peradaban bangssa yang beradab dalam rangka mencerdaskan kehidupan bangsa, bertujuan untuk berkembangnya potensi peserta didik agar menjadi manusia yang beriman dan bertaqwa kepada tuhan yang maha Esa, berahlak mulia, sehat, cakap, kreatif serta menjadi warga yang demmokratis dan bertanggung jawab (Dwi Siswoyo, 2007: 27).

Pendidikan di berbagai sekolah banyak menekankan pada nilai ulangan maupun ujian. Banyak guru yang berpandangan bahwa peserta didik dikatakan baik kompetensinya apabila nilai ulangan maupun ujiannya baik. Seperti yang sering kita lihat di media masa maupun media elektronik, yaitu mengenai sikap dan moral para pelajar yang menunjukkan perilaku negatif. Hal tersebut dikarenakan isi atau materi pendidikan tidak sepenuhnya terinternalisasi kepada peserta didik. 
Isi pendidikan yang dimaksud adalah segala sesuatu yang diberikan kepada peserta didik untuk keperluan pertumbuhan. Isi pendidikan berbeda dengan isi pelajaran. Isi pendidikan berupa nilai, pengetahuan, dan pengajaran. Sedangkan isi pengajaran adalah pengetahuan, dan ketrampilan. Hal ini berkaitan dengan mendidik, yakni trasfer nilai, pengetahuan dan ketrampilan kepada peserta didik, dan jika mengajar berarti transfer pengetahuan dan ketrampilan.

Nilai yang dimaksud adalah nilainilai kemanusiaan yang berupa pengalaman dan penghayatan manusia mengenai hal-hal yang berharga bagi hidup manusia. Nilai tersebut akan membentuk sikap dan kepribadian peserta didik pada hidup yang baik. Nilai-nilai di atas terinternalisasi melalui pembelajaran di sekolah (Kabul Budiono, 2007: 29). Disinalah peran peraturan sekolah, guru, dan semua masyarakat sekolah dalam memberikan pengaruh yang baik dalam kehidupan pribadi siswa.

Kegiatan menciptakan dan menegakkan peraturan ini merupakan proses mendefinisikan dengan jelas dan spesifik harapan guru mengenai peserta didik di sekolah. Mengetahui dan memahami peraturan yang menyatakan apa yang dibenarkan dan mana yang tidak dibenarkan sangat penting bagi peserta didik, guna untuk mengetahui apa yang harus dikerjakan dan mengetahui pelanggaran atas pertauran itu, dengan pemahaman tersebut peserta didik akan timbul kesadaran dan menunjukkan kepatuhannya terhadap peraturan. ketaatan dan kepatuhan peserta didik terhadap peraturan ini disebut disiplin.

Disiplin merupakan sesuatu yang berkenaan dengan pengendalian diri seseorang terhadap bentuk-bentuk aturan. Sikap disiplin selalu ditunjukkan kepada orang-orang yang selalu hadir tepat waktu, taat terhadap aturan, berperilaku sesuai dengan norma-norma yang berlaku. Sebaiknya, sikap yang kurang disiplin biasanya ditujukan kepada orang-orang yang tidak mentaati peraturan dan ketentuan yang berlaku, baik yang bersumber dari pemerintah, masyarakat serta sekolah.

Siswa dalam mengikuti kegiatan belajar di sekolah tidak akan lepas dari berbagai peraturan dan tata tertib yang di perlukan disekolahnya. Setiap siswa dituntut untuk dapat berperilaku sesuai dengan aturan dan tata tertib di sekolah. Kepatuhan dan ketaatan siswa terhadap berbagai aturan dan tata tertib yang berlaku di sekolah disebut disiplin siswa. Sedangkan peraturan, tata tertib dan berbagai ketentuan lainya yang berupaya mengatur perilaku siswa disebut disiplin sekolah.

Terpeliharanya disiplin tidak lepas dari terpenuhinya kepentingan atau kebutuhan para pihak. Peserta didik memiliki banyak kepentingan, guru memiliki banyak kepentingan demikian juga sekolah, namun permasalahannya adalah bagaimana kepentingan-kepentingn dari masing-masing pihak itu dapat terpenuhi dan dapat terselaraskan agar tidak terjadi bentrokan. Jika kepentingan maupun kebutuhn tersebut tidak terpenuhi akan mengganggu dalam proses pembelajaran.

Guru perlu mencermati kebutuhan maupun kepentingan peserta didik dalam menanamkan disiplin, dengan memahami sumber-sumber pelanggaran disiplin yang dilakukan. Diketahuinya sumber gangguan disiplin maka akan diketahui pula cara penanggulannganya. Disiplin yang baik adalah terjelmanya aktivitas yang mampu mengatur diri kepada terciptanya pribadi dan potensi sosial berdasar pengalamanpengalamannya sendiri. Menanamkan disiplin pada dasarnya adalah membentuk sikap dan kepribadian anak agar menjadi pribadi yang lebih baik, taat pada peraturan dan perilakunya dapat diterima di lingkungan sosialnya.

Hasil dari pendidikan dilihat dari perilaku lulusan pendidikan formal saat ini dapat dirasakan adanya berbagai ketimpangan, misalnya korupsi, perkembangan seks bebas pada kalangan remaja, tawuran, narkoba, dan perampokan yang dilakukan oleh pelajar. Untuk menghindari perilaku yang tidak diinginkan tersebut, perlu adanya cara menanamkan 
nilai disiplin yang mengarahkan siswa ke masa depan yang lebih baik.

Menanamkan disiplin yang tepat akan menghasilkan terbentuknya perilaku yang baik pada anak. Hal tersebut menyebabkan anak dapat berperilaku sesuai dengan nilai dan norma yang berlaku dilingkungan sosialnya dan sebagai hasilnya keberadaanya diterima dengan baik oleh lingkungannya. Anak demikian memiliki penyesuaian diri yang baik yang membuatnya menjadi bahagia.

Dengan demikian disiplin sangat penting untuk perkembangan anak agar ia berhasil mencapai hidup yang bahagia, mencapai penyesuaian yang baik dalam lingkungan sosialnya. Untuk mencapai keadaan tersebut disiplin perlu ditanamkan sejak awal kehidupan anak.

Upaya menanamkan nilai disiplin di sekolah mencakup setiap macam pengaruh yang ditujukan kepada peserta didik untuk membantu mereka agar dapat memahami dan menyesuaikan diri dengan tuntutan lingkungan. Disamping itu disiplin juga penting sebagai cara dalam menyelesaikan tuntutan yang mungkin ingin ditunjukkan peserta didik terhadap lingkungannya. Disiplin merupakan cara yang tepat untuk membantu peserta didik belajar hidup dengan pembiasaan yang baik, dan bermanfaat bagi dirinya maupun lingkungannya.

Berdasarkan hasil observasi yang dilakukan peneliti di SD 29 Lubuk Alung sudah menanamkan nilai disiplin. Hal ini ditunjukkan dari upaya guru dalam memberikan tindakan atau sanksi atas pelanggran terhadap peraturan sekolah yang dilakukan oleh siswa. Seperti yang diketahui peneliti ada beberapa pelanggaran terhadap peraturan sekolah yang dilakukan oleh siswa dan sanksi yang telah diberikan oleh guru.

Pelanggaran ini diantaranya, siswa sering datang telambat ke sekolah, siswa tidak memasukkan baju seragam, agar pelangaran ini tidak dilakukan terus-menerus oleh siswa, guru memberikan sanksi seperti teguran secara lisan, memperingatkan siswa supaya tidak mengulangi lagi pelanggarannya dan juga siswa jarang mengumpulkan tugas yang diberikan oleh guru, adapun sanksi yang diberikan guru terhadap pelanggaran siswa ini berupa guru menambah tugas siswa yang belum dikumpulkan.

Hal di atas menunjukkan sekolah sudah menanamkan nilai disiplin namun upaya sekolah tersebut belum dapat membuat siswa berlaku dengan disiplin. Tata tertib yang menjadi acuan utama dalam mendisiplinkan siswa di SD. Tata tertib ini didalamnya tercantum berbagai peraturan siswa dan sanksi yang diberlakukan pada siswa yang melanggar peraturan sekolah.

Masalah kurang disiplin di atas dapat disebabkan oleh upaya sekolah dalam menegakkan kebijakan kurang maksimal, seperti pemberian sanksi tidak teratur, guru terkadang memberikan sanksi terkadang tidak terhadap tindakan siswa yang melanggar peraturan, dan sanksi yang diberikan sekolah belum membuat siswa termotivasi untuk melakukan disiplin juga sekolah kurang mengupayakan cara untuk menanamkan disiplin yang dapat memotivasi siswa melakukan disiplin dalam kesehariannya di sekolah. Permasalahan dalam menanamkan nilai disiplin yang belum dapat terlaksana dengan baik di atas membuat peneliti tertarik untuk mencari tahu sejauh mana upaya sekolah dalam menanamkan nilai disiplin pada siswa di Sekolah Dasar. Peneliti juga ingin mengkaji lebih dalam adanya penanaman nilai disiplin di sekolah dasar yang belum maksimal.

Akibat dari penanaman nilai disiplin yang belum terlaksana dengan baik tersebut, sering memunculkan perilaku pelanggaran seperti yang sudah tersebut di atas dan kurangnya motivasi bagi siswa untuk melakukan disiplin dalam keseharian di sekolah, seperti ketika istirahat siswa tidak memasukkan baju seragam bahkan sampai masuk ke dalam kelas, waktu itu tidak ada guru yang menghimbau dan upaya tindakan dari pihak lain yang memberi pengawasan.

Tindakan kurang disiplin juga nampak ketika guru menyuruh siswa mengumpulkan tugas, namun kebanyakan siswa di kelas itu tidak mengumpulkannya. 
Permasalahan ini sudah berulangkali dilakukan oleh siswa dan seakan menjadi perilaku di Sekolah Dasar tersebut. Oleh karena itu penulis tertarik untuk mengadakan penelitian dengan judul "Penanaman NilaiNilai Pendidikan Karakter Disiplin Pada Siswa Sekolah Dasar". METODE PENELITIAN

Penelitian ini menggunakan pendekatan kualitatif. Sugiyono (2011: 15) menyatakan bahwa metode penelitian kualitatif adalah metode penelitian yang digunakan untuk meneliti pada kondisi objek yang alamiah, dimana peneliti sebagai instrumen kunci pengambilan data.

Teknik pengumpulan data yang digunakan dalam penelitian ini adalah wawancara, observasi, dan dokumentasi. Wawancara merupakan percakapan dengan maksud tertentu. Percakapan itu dilakukan oleh dua pihak, yaitu pewawancara (interviewer) yang mengajukan pertanyaan dan yang diwawancarai (interview) yang memberikan jawaban atas pertanyaan itu (Moleong, 2000:135). Wawancara digunakan untuk menjaring data atau informasi yang berkaitan dengan berbagai kebijakan yang dilakukan sekolah dalam pelaksanaan pendidikan karakter disiplin. Observasi dilakukan untuk melihat implementasi pendidikan karakter disiplin melalui pembelajaran di kelas. Dokumentasi digunakan untuk memperoleh data tentang tata tertib sekolah dan rencana pembelajaran yang dibuat oleh guru

Untuk memperoleh data yang dapat dipertanggungjawabkan secara ilmiah, maka dalam penelitian ini dilakukan pemeriksaan keabsahan data. Dalam penelitian ini teknik pemeriksaan keabsahan data yang digunakan adalah teknik triangulasi, yaitu teknik penyilangan informasi yang diperoleh dari sumber sehingga pada akhirnya hanya data yang absah saja yang digunakan untuk mencapai hasil penelitian (Arikunto, 2006:18). Teknik triangulasi dilakukan dengan cara triangulasi metode, yaitu dengan mengecek ulang informasi hasil wawancara dengan dokumentasi dan observasi. Teknik analisis data yang digunakan dalam penelitian ini adalah teknik analisis induktif, yaitu analisis yang bertolak dari data dan bermuara pada simpulan-simpulan umum kesimpulan.

\section{HASIL DAN PEMBAHASAN}

Dalam upaya mendukung keberhasilan pendidikan karakter disiplin di SD 29 Lubuk Alung dilakukan berbagai kebijakan oleh sekolah. Dalam pelaksanaan kebijakan tersebut sekolah menjalin kerjasama yang baik antara kepala sekolah, guru, karyawan, orang tua, dan komite sekolah. Berbagai kebijakan yang dilakukan SD 29 Lubuk Alung tersebut adalah sebagai berikut.

\section{Program Pendidikan Karakter}

Program pendidikan karakter merupakan salah satu program sekolah yang dilaksanakan di SD 29 Lubuk Alung. Di dalam program pendidikan karakter ini salah satu yang dikembangkan adalah karakter disiplin. Penyusunan program pendidikan karakter dilakukan dengan melibatkan guru, orang tua, dan siswa. Hal ini mengingat bahwa untuk mendukung keberhasilan program pendidikan karakter perlu campur tangan baik dari pihak sekolah (guru), orang tua, dan masyarakat.

\section{Menetapkan Aturan Sekolah dan Aturan Kelas}

Aturan sekolah maupun aturan kelas berperan penting dalam mendisiplinkan siswa. Pentingnya aturan sekolah ini dikemukakan oleh Curvin \& Mendler (1999:8) bahwa terjadinya perilaku tidak disiplin pada siswa salah satu faktor penyebabnya adalah pembatasan yang tidak jelas. Dengan dituangkannya aturan sekolah maupun aturan kelas ke dalam tata tertib sekolah, maka batasan-batasan perilaku siswa di sekolah menjadi jelas.

Agar aturan sekolah maupun aturan kelas yang telah dibuat dapat dilaksanakan dengan baik, maka perlu dilakukan sosialisasi kepada orang tua siswa. Kegiatan ini dilakukan di awal tahun pelajaran oleh guru kelas. Kegiatan sosialisasi ini penting dilakukan agar orang tua dapat menjaga konsistensi pemberlakuan aturan di sekolah 
dengan di rumah sehingga terjadi kontinuitas dalam penegakkan disiplin yang dilakukan di sekolah dan di rumah.

\section{Melakukan Sholat Dhuha dan Sholat Dzuhur Berjamaah}

Salah satu kegiatan untuk menegakkan kedisiplinan di SD 29 Lubuk Alung adalah melalui kebijakan sholat berjamaah, yaitu untuk sholat dhuha dan sholat dhuhur. Melalui kegiatan sholat berjamaah ini siswa dilatih untuk tertib dalam melakukan ibadah, baik mulai persiapan, pelaksanaan hingga mengakhiri ibadah. Kegiatan sholat berjamaah ini diwarnai dengan pembiasaan-pembiasaan yang berkaitan dengan pengkondisian siwa untuk berdisiplin dalam beribadah.

\section{Membuat Pos Afektif di Setiap Kelas}

Pos afektif merupakan salah satu kebijakan yang dilakukan SD 29 Lubuk Alung guna menginternalisasikan nilai-nilai karakter kepada siswa, termasuk di dalamnya nilai karakter disiplin.

Kegiatan pos afektif akan difokuskan pada pembinaan kepada siswa dalam hal berperilaku tertib dalam memasuki kelas, melangkah, mengucap salam, berjabat tangan, meletakkan tas, dan sebagainya. Pada pagi hari guru kelas bersama siswa yang bertugas di hari itu sudah siap di depan kelas untuk melakukan penyambutan terhadap siswa yang datang di kelas. Melalui kegiatan pos afektif ini siswa dilibatkan secara aktif dalam penegakan disiplin di SD 29 Lubuk Alung.

Memantau Perilaku Kedisiplinan Siswa di Rumah Melalui Buku Catatan Kegiatan Harian

Buku catatan kegiatan harian merupakan salah satu kebiajakan yang dilakukan di SD 29 Lubuk Alung untuk memantau perilaku disiplin siswa di rumah. Buku ini merupakan alat bagi guru untuk memantau kegiatan siswa di rumah dalam hal disiplin beribadah, belajar, dan kegiatan lain yang terkait dengan pengembangan disiplin siswa.

Adanya buku catatan kegiatan harian siswa bertujuan untuk menjaga konsistensi antara kegiatan siswa di sekolah dan di rumah. Konsistensi ini perlu dipantau dan dijaga untuk mendukung keberhasilan program pendidikan karakter disiplin yang sedang dikembangkan.

Devine (2002:310) mengemukakan bahwa dalam rangka untuk mendisiplinkan siswa perlu dilakukan kontrol waktu dan ruang sebagai alat untuk memonitoring perilaku siswa. Melalui kontrol ruang dan waktu diharapkan secara bertahap akan muncul kesadaran diri siswa untuk berperilaku disiplin.

\section{Melibatkan Orang Tua dalam Pendidikan Karakter Disiplin}

Keterlibatan orang tua dalam mendukung keberhasilan pendidikan karakter disiplin yang dilakukan sekolah adalah hal penting yang tidak boleh diabaikan. Kegiatan ini dilakukan dengan tujuan agar orang tua dapat melakukan program pendidikan karakter disiplin yang dikembangkan di sekolah dalam kegiatan anak sehari-hari di rumah.

di samping itu orang tua juga akan memberikan informasi tentang berbagai hal terkait dengan kegiatan atau perilaku anak di rumah. Jika perilaku tersebut positif, maka diberikan penguatan, sementara jika perilakunya menyimpang atau negatif, maka bersama- sama antara orang tua dan guru untuk mengatasinya.

\section{Melibatkan Komite Sekolah dalam Pendidikan Karakter Disiplin}

Unsur komite sekolah merupakan bagian

dari masyarakat yang terlibat dalam pendidikan karakter disiplin. Masyarakat yang dalam hal ini diwakili oleh komite sekolah memiliki peran yang penting dalam mendukung keberhasilan Pendidikan Karakter Disiplin di Sekolah Dasar. Alasan perlunya masyarakat terlibat dalam pendidikan karakter disiplin mengingat bahwa interaksi anak tidak hanya terbatas dengan guru dan teman sebaya serta orang tua saja, tetapi mereka juga berinteraksi dengan masyarakat lain yang lebih luas.

Pentingnya keterlibatan masyakarakat yang dalam hal ini diwakili oleh komite sekolah didasari dengan alasan bahwa masyarakat baik secara langsung maupun 
tidak langsung akan memberikan pengaruh

Pendidika. Bandung. Alfabeta yang positif terhadap pembentukan karakter peserta didik. Hal ini senada dengan pendapat Mulyasa (2011:75) bahwa terdapat pengaruh yang diberikan oleh lingkungan masyarakat yang positif terhadap pembentukan karakter peserta didik.

\section{KESIMPULAN}

Berdasarkan penelitian yang dilakukan di SDN 29 Lubuk Alung ini dapat disimpulkan bahwa untuk mendukung tercapainya keberhasilan nilai karakter disiplin di sekolah ini, dibuat tujuh kebijakan sekolah, yaitu program pendidikan karakter, menetapkan aturan sekolah dan aturan kelas, melakukan sholat Dhuha dan Sholat Dzuhur berjamaah, membuat pos afektif di setiap kelas, memantau perilaku kedisiplinan siswa di rumah melalui buku catatan kegiatan harian, dan melibatkan orang tua, dan melibatkan komite sekolah.

Dalam pelaksanaan keenam kebijakan tersebut perlu dukungan dari seluruh warga sekolah baik kepala sekolah, guru, orang tua, komite sekolah, karyawan, dan siswa. Di samping itu, juga perlu perencanaan yang matang untuk menyusun program-program sekolah. Dalam pelaksanaannya juga perlu konsistensi yang kuat dari seluruh warga sekolah, terutama dalam hal pelaksanaan program dan penegakan aturan sekolah maupun aturan kelas.

\section{DAFTAR PUSTAKA}

Arikunto, Suharsimi. (2006). Prosedur penelitian (suatu pendekatan praktik). Jakarta: Rineka Cipta.

Curvin, R. L., \& Mindler, A. N. 1999. Discipline With Dignity. USA: Association For Supervision And Curriculum Development.

Dwi Siswoyo, dkk. (2007). Ilmu Pendidikan. Yogyakarta: Uny Press.

Moleong, L. J. 2007. Metode Penelitian Kualitatif. Bandung: Remaja Rosda Karya

Mulyasa, E. 2011. Manajemen Pendidikan Karakter. Jakarta: Bumi Aksara.

Sugiyono. (2011). Metode Penelitian 
ISSN $1411-3570$

eISSN 2579-9525 